\title{
The Influence of Grammatical Gender on Russian and Thai Speakers' Cognition
}

\author{
Kusuma Thongniam (กุสุมา ทองเนียม) \\ MA graduate, Department of Linguistics, Faculty of Arts, \\ Chulalongkorn University, Bangkok, Thailand \\ kusuma.thn@gmail.com \\ Amara Prasithrathsint (อมรา ประสิทธิ์รัฐสินธุ์) \\ Professor Emeritus of Linguistics, Department of Linguistics, Faculty of Arts, \\ Chulalongkorn University, Bangkok, Thailand \\ amaraprasithrathsint@gmail.com
}

\begin{abstract}
The aim of this study is to investigate the influence of grammatical gender on Russian speakers' cognition, compared with Thai speakers' cognition by means of object categorization. The key materials in the experiment are black-and-white pictures represented by nouns that are selected based on gender and appearance similarity. The hypothesis is that Russian speakers group two pictures that belong to the same grammatical gender class together, while Thai speakers generally rely on the size or shape of objects in the pictures. The result of the experiment statistically showed that Russian speakers categorized things on the basis of grammatical gender, while Thai speakers categorized things represented by things grouped on the basis of size or shape. Additionally, the result implies that bilingualism is a very important variable in a study testing the Linguistic Relativity Hypothesis.
\end{abstract}

\section{Keywords}

Linguistic Relativity - grammatical gender - bilingualism 
บทคัดย่อ

อิทธิพลของเพศทางไวยากรณ์ต่อปริชานของผู้พูดภาษารัสเซียและผู้พูดภาษาไทย งานวิจัยนี้มีวัตถุประสงค์เพื่อทดสอบอิทธิพลของเพศทางไวยากรณ์ต่อระบบปริชานของผู้พูด ภาษารัสเซียซึ่งเป็นภาษาที่มีเพศทางไวยากรณ์เปรียบเทียบกับระบบปริชานของผู้พูดภาษาไทย ซึ่ง เป็นภาษาที่ไม่มีเพศทางไวยากรณ์ โดยทดสอบพฤติกรรมทางปริชานของคนรัสเซียและคนไทย ด้านการจำแนกประเภทของวัตถุ ผู้วิจัยคัดเลือกภาพของวัตถุที่แทนคำนามในภาษารัสเซีย ที่สอด คล้องกับเพศทางไวยากรณ์ของคำนามและขนาดหรือรูปร่างของวัตถุ สมมติฐานของงานวิจัยนี้คือ ผู้พูดภาษารัสเซียจำแนกวัตถุสิ่งของตามเกณฑ์เพศทางไวยากรณ์ของคำนามในภาษารัสเซียมาก กว่าผู้พูดภาษาไทย ในขณะที่ผู้พูดภาษาไทยจำแนกสิ่งของตามเกณฑ์ของขนาดหรือรูปร่างของวัตถุ มากกว่า ผลการศึกษาเป็นไปตามสมมติฐาน กล่าวคือ ผู้พูดภาษารัสเซียจัดกลุ่มวัตถุสิ่งของตามเพศ ทางไวยากรณ์มากกว่าผู้พูดภาษาไทยและผู้พูดภาษาไทยมีแนวโน้มที่จะจัดกลุ่มสิ่งของตามขนาด หรือรูปร่างของวัตถุมากกว่าผู้พูดภาษารัสเซีย นอกจากนั้น งานวิจัยนี้ยังแสดงเป็นนัยว่า ภาวะสอง ภาษาอาจเป็นตัวแปรสำคัญในการวิจัยเพื่อทดสอบสมมติฐานภาษาสัมพัทธ์

\section{Introduction $^{1}$}

Do languages influence the way people think? This has often been a topic that laypeople talk about and many researchers have tried to investigate. This question is related to the Linguistic Relativity Hypothesis, which claims that a particular language influences its speakers' thought. This hypothesis is also known as the Sapir-Whorf Hypothesis or the Whorfian Hypothesis after Benjamin Lee Whorf (1956), who proposed the "Linguistic Relativity principle", which states:

Users of markedly different grammars are pointed by their grammars toward different types of observations and different evaluation of externally similar acts of observation, and hence are not equivalent as observers but must arrive at somewhat different views of the world. (Whorf 1956, 221)

The main idea of the hypothesis is that the grammatical system of a language influences its speakers' world view or cognition. Speakers of languages with similar grammatical systems have more similar perceptions and conceptions of reality than those of speakers of languages with different grammatical systems.

1 The paper is part of the first author's Master's dissertation entitled The Effect of Grammatical Gender on Cognition of Russian-English Bilinguals Compared with Russian Monolinguals and English Monolinguals. 
How do we investigate the influence of a language on its speakers' cognition? This is the question facing scholars who are interested in testing the Linguistic Relativity Hypothesis. Because cognition is a mental process, it is very difficult to test or cannot be directly investigated. However, cognitive researchers such as Pecher and Zwaan (2005) and Eysenck and Keane (2005) have pointed out that a mental process covers various activities, such as attention, perception, learning, memory, solving and thinking. This seems to suggest that it is possible to investigate cognitive behavior. Indeed, Lucy (1992) proposed that cognition could be examined by observing speakers' cognitive behavior such as attention, memory and categorization. Furthermore, Lakoff (1987) claimed that categorization was a human's basic process of thinking, perceiving, performing and using language. When seeing the differences between things, we are unconsciously categorizing. This leads to the conclusion that we can investigate the influence of language on its speakers' cognition through cognitive behavior, especially categorization. In fact, the present study seems to adequately serve as an example of that approach.

Among previous studies that have investigated the influence of language on its speakers' cognition, Lucy (1992) seems to be regarded as a pioneer of study that aims to test the Linguistic Relativity Hypothesis. He focuses on three grammatical categories, namely, number, countable/uncountable nouns and classifiers. He aims to test to what extent those grammatical categories influence the cognition of English speakers and Yucatec Maya speakers through certain cognitive behavior; i.e., memory and categorization. The results of Lucy's study show that English speakers were better at memorizing the number of objects than speakers of Yucatec Maya when he asked them to describe things in pictures. In addition, when they were asked to group two from three similar objects, English speakers grouped similar objects by the shape of the objects, while the speakers of Yucatec Maya did so by their substance. Lucy explains that because English differentiates clearly between singular and plural forms of nouns, speakers of English are more aware of the numbers of things than speakers of Yucatec Maya, a language without number marking on nouns, except for some animate nouns where it is optional. Also, as English divides nouns into countable and uncountable, English speakers tend to pay attention to the shape of things whereas Yucatec Maya uses classifiers to mark the substance of nouns. This study leads to the conclusion that grammatical number, countable/uncountable nouns and classifiers influence the speakers' cognition. On the same lines, Charunrochana (2000), studied the influence of grammatical number and countable nouns in English and classifiers in Thai on the speakers' cognition, and found that English speakers were better at memorizing the number of objects than Thai speakers. This is similar to what Lucy 
reported. Also, her experiment in classifying things shows that English speakers tend to pay more attention to the shape of things. However, this study yields a result that is different from Lucy's; i.e., speakers of Thai, a language with classifiers, and English speakers are not statistically different in classifying things according to substance. Considering that the results turned out to be the same, we can conclude that the studies by Lucy and Charunrochana support the claim that grammatical number and countable/uncountable nouns influence speakers' cognition.

In addition, Chandharath (2013) investigated the influence of linguistic honorifics on Japanese, Thai and English speakers. Japanese employs honorifics at a morpho-syntactic level, while Thai and English only have it as an optional word to signal politeness. To investigate the influence of linguistic honorifics on cognitive behavior, participants were asked to arrange 4-5 pictures of people and objects in a hierarchical order according to whatever criteria they preferred. The results of the study show that Japanese speakers tend to arrange things and people according to age and status hierarchy while Thai speakers and English speakers use other criteria, such as color and size. Chandharath concludes that speakers of languages in which the linguistic markers of honorifics are obligatory, such as Japanese, pay more attention to age and the status of things and people than speakers of languages in which honorific forms are optional. In other words speakers of Japanese whose grammar is different from English and Thai with reference to obligatory honorific marking, show cognitive behavior that is different from that of speakers of Thai and English, which have different grammars. This seems to support the Linguistic Relativity Hypothesis. We can also infer from this that the study implies that the grammar of a language has influence on its speakers' cognition.

Another study by Aemdit (2015) shows clearly the influence of grammatical categories on cognition. The purpose of the research was to investigate the relationship between grammatical tense marking and the cognitive system shown in the behavior of English, Japanese, Chinese and Thai speakers. She hypothesized that speakers of tense languages such as English and Japanese are more aware of time and memorize it better than speakers of tenseless languages such as Thai and Chinese. To test this hypothesis, speakers of the four languages were asked to do a picture-selecting task and answer two types of question, one gap-filling and one multiple-choice, while watching a video clip. In all the tasks there were hidden keys of time to test the participant's memory such as whether participants mentioned a clock in the picture or whether they could remember the exact time something happened in a clip. The results of this study showed the influence of grammatical tense marking on an awareness of time. 
From the review of the literature, we found that most of the studies support the Linguistic Relativity Hypothesis. We are interested in the relationship between grammatical gender and the cognitive system and we are curious to learn to what extent it can affect the speaker's cognitive behavior. This leads to the purpose of the present study; i.e, to discover the difference between speakers of a language with grammatical gender and those who speak a language without grammatical gender in terms of their cognitive behavior.

\section{Grammatical Gender and the Linguistic Relativity Hypothesis}

Since grammatical gender is the focus of this study, it may be a good idea to give a brief account of it before getting to the experiment part. Therefore, in this section, we will give a brief explanation of this grammatical category. Grammatical gender is a device used by certain languages to group nouns into sub-classes. All European languages, except English, have obligatory gender differentiation. Some gendered languages divide nouns into two groups according to gender; i.e., masculine and feminine, such as French, Spanish and Italian. Others have three genders; i.e., masculine, feminine and neuter, such as German and Russian. The criteria for dividing nouns into genders are somewhat arbitrary. According to Corbett (1991), we cannot clarify a rule underlying the division of gendered nouns. Although genders of nouns with regard to humans are mostly predictable by the humans' biological sex, it is not the case for words which refer to objects. Across gendered languages, a word referring to the same concept may be different in grammatical gender; for example, the term 'sun' is masculine in Spanish sol, feminine in German sonne and neuter in Russian 'sonts. Moreover, Boutonnet et al. (2012), studied the diachronic aspect of grammatical gender and found that, in some languages, there are certain words whose grammatical gender has shifted from what it was in the past. For example, the term 'girl' in the Polish language was feminine in the past (ta dziewczyna) but is neuter nowadays (to dziewcze).

Even though grammatical gender is directly related to nouns, it is covert with reference to the marking of gender on nouns. However, gender markers are clear on words occurring with nouns. For instance, the forms of adjectives and determiners must be differentiated by gender in order to be grammatically correct.

Our review of past studies concerning grammatical gender and the Linguistic Relativity Hypothesis show that they mostly deal with Italian (Kousta et al. 2008), Spanish (Flaherty 2001; Cubelli et al. 2011; Boroditsky et al. 2003), French (Forbes et al. 2008) and German (Charunrochana 1999; Boroditsky et al. 2003) 
and Hindi (Charunrochana 1999). Most of the results of the reviewed studies show the effects of grammatical gender on people's thoughts about things in the world. For example, Flaherty (2001) found that when Spanish speakers were asked to assign a typical male or female name to each drawing of objects, they assigned a name that was consistent with the gender of that object. Another of the researches, Boroditsky et al. (2002 cited in Boroditsky et al. 2003, 61-79) found that grammatical gender has influence on the speaker's ability to memorize objects and details about them by giving objects proper names that are either consistent or inconsistent with Spanish and German grammatical gender. Boroditsky et al., found that Spanish speakers and German speakers were better at remembering proper names whose gender corresponds to the gender of objects. In addition, when Spanish speakers and German speakers were asked to write down a list of the three adjectives describing each object the result was that they wrote down adjectives that were gender-consistent in their language with the objects, even if the adjectives were in English.

Furthermore, Boroditsky et al. (2002 cited in Boroditsky et al. 2003, 61-79), explored the relationship between grammatical gender and biological sex. They asked Spanish speakers and German speakers to rate the similarity of pictures of people-object pairs. They found that Spanish speakers and German speakers rated the pairs that had the same gender higher. Another example of studies that examine the relationship between grammatical gender and biological sex is Charunrochana (1997). She chose German to stand for a language with three genders and Hindi for a language with two genders. A sample of German and Hindi participants was asked to look at pictures showing some stories mostly about animals and write down descriptions of what they saw. The pictures were intentionally created so as to make grammatical gender conflict with biological sex, for example, a story about a female elephant (Elefant is a masculine noun in German.) It was found that both German and Hindi participants consistently used grammatical gender marking with nouns without paying attention to the biological sex when describing stories in pictures. For instance, in describing a pregnant elephant, a German participant would use a masculine determiner, adjective and pronoun even though the elephant was clearly depicted as a female animal in the story. The evidence above seems to imply that grammatical gender is so important that it makes native speakers overrule the real biological sex of things they are talking about.

Very little research has been found that concentrates on Russian where gender exhibits considerable significance in the grammar. One of the few previous studies, Jakobson (1966) found that when Russian speakers were asked to match days of the week to humans, they consistently matched a human gender with the same grammatical gender of the day. They matched Monday, Tuesday 
and Thursday to males and Wednesday, Friday and Saturday to females. The study showed that Grammatical gender in Russian influences the decision to categorize things. Another study done by Doleschal (1993 and 1997 cited in Alvanoudi, 2014, 66) did not experiment on cognitive behavior but only on linguistic behavior. It aimed to explore the relationship between language and sexism in Russian. A sample of Russian speakers was asked to give proper names for masculine nouns. The results indicated that the majority of the Russian participants interpreted the nouns in question as male, such as the masculine noun $v$ rag 'enemy' and the masculine noun avtor 'author', except for a small number of examples which the author believed to be the result of the participants' knowledge of the stereotypes constructed by the society, such as the masculine noun 'doctor' being given a female name. This is probably because most doctors were women in the Soviet period.

Even though the studies of gender mentioned above confirm the prominence of grammatical gender, the experiments in these studies involved the explicit use of languages such as through describing stories in pictures, making it unclear whether the different cognitive behavior among participants came from the grammatical categories in question or the choices of languages that differed from one experiment set-up to another. To solve this problem, we propose a way to perform an experiment that relies solely on non-linguistic tasks in order to keep the participants away from the possible undesirable guidance of any language. More specifically, we are interested in the influence of grammatical gender on Russian speakers' cognition. Firstly, we will discuss the role of grammatical gender in Russian for any reader who might not be familiar with it.

\section{3}

The Role of Grammatical Gender in the Russian Language

Russian is an East Slavonic language, which is a gendered language. It has three genders: masculine, feminine and neuter. The three genders constitute the complex grammatical system of Russian. For example, the grammatical gender of a noun dictates the behavior of an adjective or a verb in the past tense, requiring them to occur in a gender-agreed form in a sentence.

Examples of the gender agreement between nouns and adjectives

большой учебник

bal'shoy uchebnik

big.ADJ.MAS textbook.NOUN.NOM.MAS

'big textbook' 


$\begin{array}{lc}\begin{array}{l}\text { большая книга } \\ \text { bal'shaya }\end{array} & \text { kniga } \\ \text { big.ADJ.FEM } & \text { book.NOUN.NOM.FEM } \\ \text { 'big book' } & \\ & \\ \text { бoльшое дерево } & \text { dereva } \\ \text { bal'shoye } & \text { tree.NOUN.NOM.NEU } \\ \text { big.ADJ.NEU } & \\ \text { 'big tree' } & \end{array}$

As the examples show, the adjective bal'shoy 'big' changes to bal'shoy when it modifies a masculine noun uchebnik 'texbook' but when it modifies a feminine noun, kniga 'book', the form bal'shaya is used instead. Furthermore, the form bal'shoye occurs when it modifies a neuter noun dereva 'tree'. All of the three forms have the same meaning 'big'.

Examples of gender agreement between nouns and verbs in the past tense

\author{
Студент стоял. \\ stodj'ent stej'cel \\ student.MAS.NOM stand.vERB.PAST.MAS \\ 'A male student stood.' \\ Студентка стояла. \\ studj'entka stej'cela \\ student.FEM.NOM stand.VERB.PAST.FEM \\ 'A female student stood.'
}

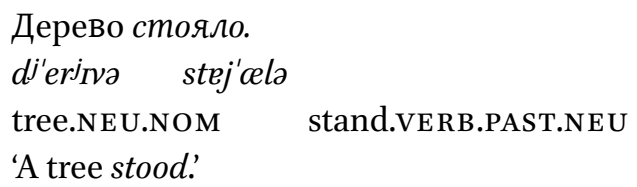

From the examples above, the gender of nouns in the nominative case determines the gender of the verb following. The verb stej'cet (стоять) 'stand' becomes stej'æel (стоял) when it occurs with a masculine nominative noun, stej'cela (стояла) with a feminine nominative noun and stej'cla (стояло) with a neuter nominative noun.

In addition to gender agreement, there is case agreement and number agreement in Russian. Every noun has a total of 12 forms, two for number, singular and plural, and each one also has six possible cases as shown below. 
TABLE 1 Inanimate noun paradigm in Russian

\begin{tabular}{llll}
\hline & Masculine & Feminine & Neuter \\
\hline \multicolumn{1}{c}{ Singular } & & & \\
Nominative & zakon & škola & vino \\
Accusative & zakon & školu & vino \\
Genitive & zakona & školy & vina \\
Dative & zakonu & škole & vinu \\
Instrumental & zakonom & školoj & vinom \\
Locative & zakone & škole & vine \\
\multicolumn{1}{c}{ Plural } & & & \\
Nominative & zakony & školy & vina \\
Accusative & zakony & školy & vina \\
Genitive & zakonov & škol & vin \\
Dative & zakonam & školam & vinam \\
Instrumental & zakonami & školami & vinami \\
Locative & zakonax & školax & vinax \\
& 'law' & 'school' & 'wine' \\
\hline
\end{tabular}

(SOURCE: ADAPTED FROM CORBETT 1991, 36)

By contrast, in a genderless language like Thai, the adjectival verb sǔr 'tall' and action verb lóm (ล้ม) 'fall' never change in form regardless of the noun they occur with as in the following examples.

Examples of the adjectival verb sǔry 'tall' in Thai

ผู้ชายคนนั้นสูง

$p^{h} \hat{u}$. c $c^{h} a: j k^{h}$ on nán sǔry

man.NOUN.NOM person.CLS that.DET tall.vERB

'That man is tall.'

ผู้หญิงคนนั้นสูง

$p^{h} \hat{u}:$. ǰ̌ $k^{h}$ on nán sǔ:y

woman.NOUN.NOM person.CLS that.DET tall.vERB

'That woman is tall.'

ต้นไม้ต้นนั้นสูง

tôn.má:j tôn nán sǔ:y 
tree NOUN thing.CLS that.DET tall.vERB.

'That tree is tall.'

Examples of the action verb lóm (ล้ม) 'fall' in Thai

เด็กผู้ชายล้ม
dèk.pû:.ch a.j lóm
boy.NOUN.NOM fall.vERB
'A boy falls.'
เด็กผู้หญิงล้ม
dèk.pû̀:jüy lóm
girl.NOUN.NOM fall.vERB
'A girl falls.'
ต้น'ม้ล้ม
tôn.má:j lóm
tree.NOUN.NOM fall.vERB
'A tree falls.'

Since grammatical gender is an important element in Russian, it is possible that part of Russian speakers' cognition, if influenced by the Russian language, will be different from that of a speaker of genderless languages like English and Thai. Consequently, we are interested in testing the Linguistic Relativity Hypothesis by conducting an experiment which focuses on Russian and Thai speakers.

\section{$4 \quad$ Methodology}

To answer whether grammatical gender has an influence on Russian speakers' cognition compared to that of Thai speakers' we chose a method of experiment through a non-linguistic task, using pictures of various things that represent nouns in Russian to examine the difference in the participants' categorization habits.

We hypothesize that grammatical gender has an influence on Russian speakers' cognition as reflected through their choices in the picture grouping 
experiment, that is, they are likely to group pictures denoting nouns of the same gender together. On the other hand, gender has no influence on Thai speakers and they tend to group pictures of the same size or shape together.

\section{Materials used in the Experiments}

To prepare stimuli for the above-mentioned experiment, we selected a total of ${ }_{27}$ Russian nouns to make up the 9 sets of the object categorization test. Principles for word selection were:

1. Within a 3-word set, two of them had to match in gender while differing in shape/size or vice versa.

2. The nouns were to be selected so that all the three genders (masculine, feminine and neutral) were covered.

3. All the nouns were divided into two groups: natural object-denoting nouns and artifact-denoting nouns.

Every word was represented by a corresponding black-and-white picture; for example. rutf'kә (ру́чка) 'pen' was a black-and-white picture of a pen. We used black-and-white pictures in order to prevent the possibility of colors intervening in the categorization procedure. As stated above, this experiment utilized 9 sets of pictures for 27 nouns, resulting in 3 pictures for each set. One of them was an exemplar, and the other two were designed to be related to it. One matched it in terms of gender and another in terms of size or shape. Therefore, there were three pictures in one set. One picture served as the key, while the other two were for the subjects in the experiment to choose from according to their consideration as to which of the two pictures was more similar to the exemplar picture given. The list of words used in the experiment and their corresponding picture is shown below.

According to the example of a set of natural objects (Figure 1), we hypothesized that for the exemplar $e p$ ' $b t^{\prime} s^{\prime}$ in 'orange' given in Figure 1, Russian speakers would select choice 1: benan 'banana' because they are both masculine in Russian in spite of their different shapes. With no influence from grammatical gender, Thai speakers would select choice 2: cebtəka 'apple' due to its similarity in shape.

According to the example of a set of artifacts (Figure 2), the hypothesis was that Russian speakers would select choice 1: botttka 'bottle' because it is feminine, the same gender as the exemplar rutf'ka 'pen'. However, Thai speakers would select choice 2: noz 'knife' because a knife and a pen have similar shape. 
TABLE 2 list of words used in the experiment and their corresponding picture

\begin{tabular}{|c|c|c|c|c|c|c|c|}
\hline $\begin{array}{l}\text { Type of } \\
\text { group }\end{array}$ & Set & Picture & Meaning & Word & $\begin{array}{l}\text { Russian } \\
\text { grammatical } \\
\text { gender }\end{array}$ & $\begin{array}{l}\text { Size or } \\
\text { Shape }\end{array}$ & $\begin{array}{l}\text { Relation } \\
\text { with the } \\
\text { exemplar }\end{array}$ \\
\hline \multirow[t]{12}{*}{ nature } & 1 & Exemplar & orange & $\begin{array}{l}\text { апельси́н } \\
\text { /ер'ьł's'in/ }\end{array}$ & masculine & spherical & \\
\hline & & choice & apple & $\begin{array}{l}\text { я́блоко } \\
\text { /æbłəkə/ }\end{array}$ & neuter & spherical & shape-related \\
\hline & & choice & banana & $\begin{array}{l}\text { бана́н } \\
\text { /benan/ }\end{array}$ & masculine & $\begin{array}{l}\text { long- } \\
\text { shaped }\end{array}$ & gender-related \\
\hline & 2 & Exemplar & zebra & $\begin{array}{l}\text { зе́бра } \\
\text { /z'ebrə/ }\end{array}$ & feminine & slim & \\
\hline & & choice & giraffe & $\begin{array}{l}\text { жира́ф } \\
\text { /zəraf/ }\end{array}$ & masculine & slim & shape-related \\
\hline & & choice & panda & $\begin{array}{l}\text { па́нда } \\
\text { /pandə/ }\end{array}$ & feminine & fat & gender-related \\
\hline & 3 & Exemplar & squirrel & $\begin{array}{l}\text { бе́лка } \\
\text { /b'ełkə/ }\end{array}$ & feminine & small & \\
\hline & & choice & fox & $\begin{array}{l}\text { лиса́ } \\
\text { /ł'ssa/ }\end{array}$ & feminine & big & gender-related \\
\hline & & choice & rabbit & $\begin{array}{l}\text { кро́лик } \\
\text { /kroł'ьk/ }\end{array}$ & masculine & small & size-related \\
\hline & 4 & Exemplar & $\begin{array}{l}\text { watermel- } \\
\text { on }\end{array}$ & $\begin{array}{l}\text { арбу́з } \\
\text { /erbus/ }\end{array}$ & masculine & big & \\
\hline & & choice & pumpkin & $\begin{array}{l}\text { тьі́ква } \\
\text { /tikvə/ }\end{array}$ & feminine & big & size-related \\
\hline & & choice & grape & $\begin{array}{l}\text { виногра́д } \\
\text { /v'ьnegrat/ }\end{array}$ & masculine & small & gender-related \\
\hline \multirow[t]{5}{*}{ artifact } & 5 & Exemplar & saucepan & $\begin{array}{l}\text { кастрю́ля } \\
\text { /kestr'jut'ь/ }\end{array}$ & feminine & $\begin{array}{l}\text { bowl- } \\
\text { shaped }\end{array}$ & \\
\hline & & choice & tea pot & $\begin{array}{l}\text { ча́йник } \\
\text { /t f'ajn'ьk/ }\end{array}$ & masculine & $\begin{array}{l}\text { bowl- } \\
\text { shaped }\end{array}$ & shape-related \\
\hline & & choice & fork & $\begin{array}{l}\text { ви́лка } \\
\text { /v'iłkə/ }\end{array}$ & feminine & $\begin{array}{l}\text { long- } \\
\text { shaped }\end{array}$ & gender-related \\
\hline & 6 & Exemplar & bucket & $\begin{array}{l}\text { ведро́ } \\
\text { /v'sdro/ }\end{array}$ & neuter & $\begin{array}{l}\text { bowl- } \\
\text { shaped }\end{array}$ & \\
\hline & & choice & window & $\begin{array}{l}\text { окно́ } \\
\text { /ekno/ }\end{array}$ & neuter & square & gender-related \\
\hline
\end{tabular}


TABLE 2 list of words used in the experiment and their corresponding picture (Cont.)

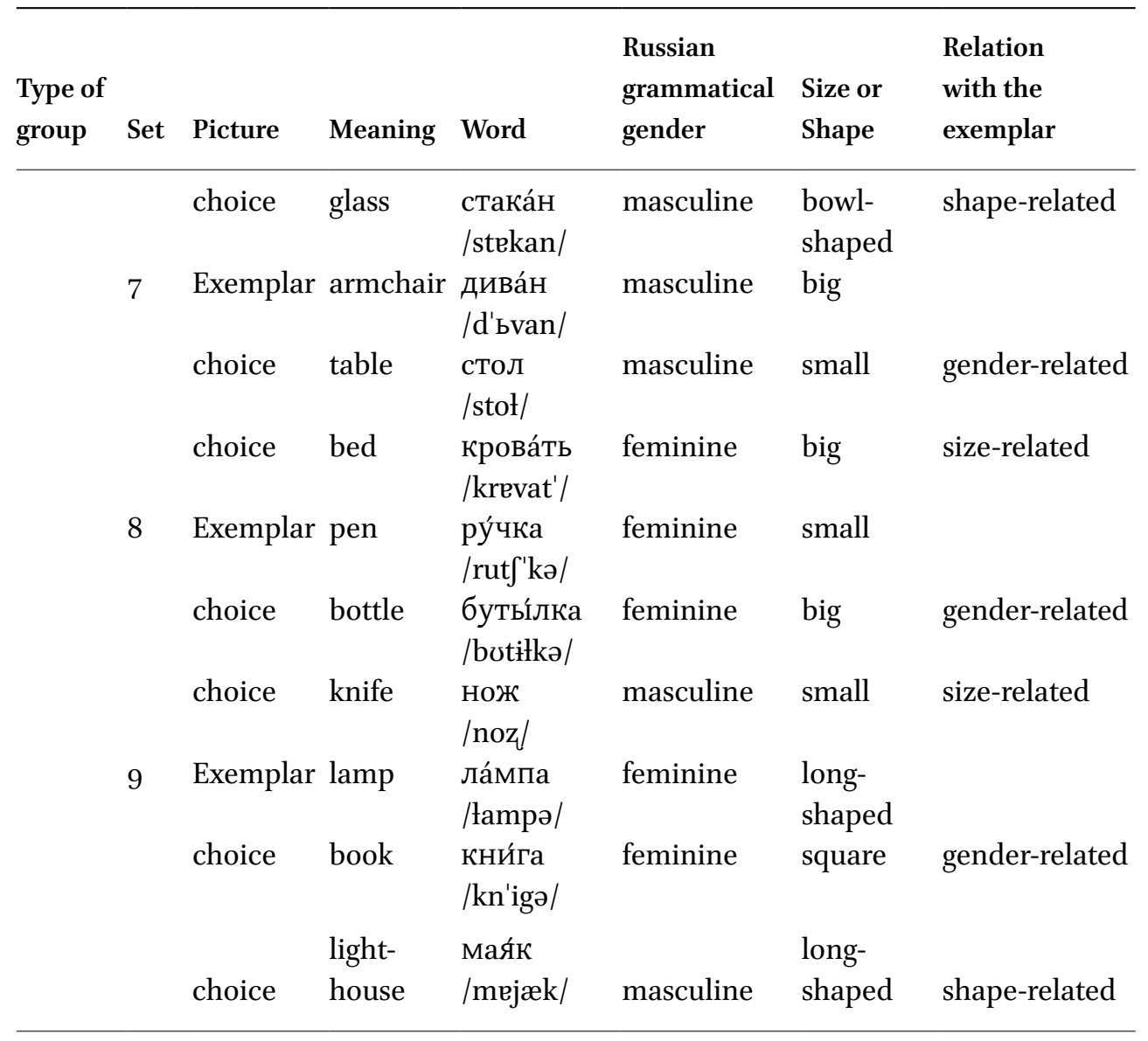

In order to conceal the aim of this experiment from the participants, we provided two "placebo" or control sets. The pictures in these sets were similar in all aspects, shape, size and gender. For example, an exemplar was sebaka 'dog', which is feminine and has a small size. We provided for it choice 1: keata 'koala' and choice 2: koska 'cat'; both of which are both feminine and of small size.

For the quantitative scoring analysis of the test we determined that selecting a picture that corresponds to Russian grammatical gender would get one point and that selecting otherwise would earn zero points. The two control sets would not be counted in the calculation, i.e., the maximum score the participants could get would be 9 for each participant. The answer sheet on paper for the experiment was composed of three 


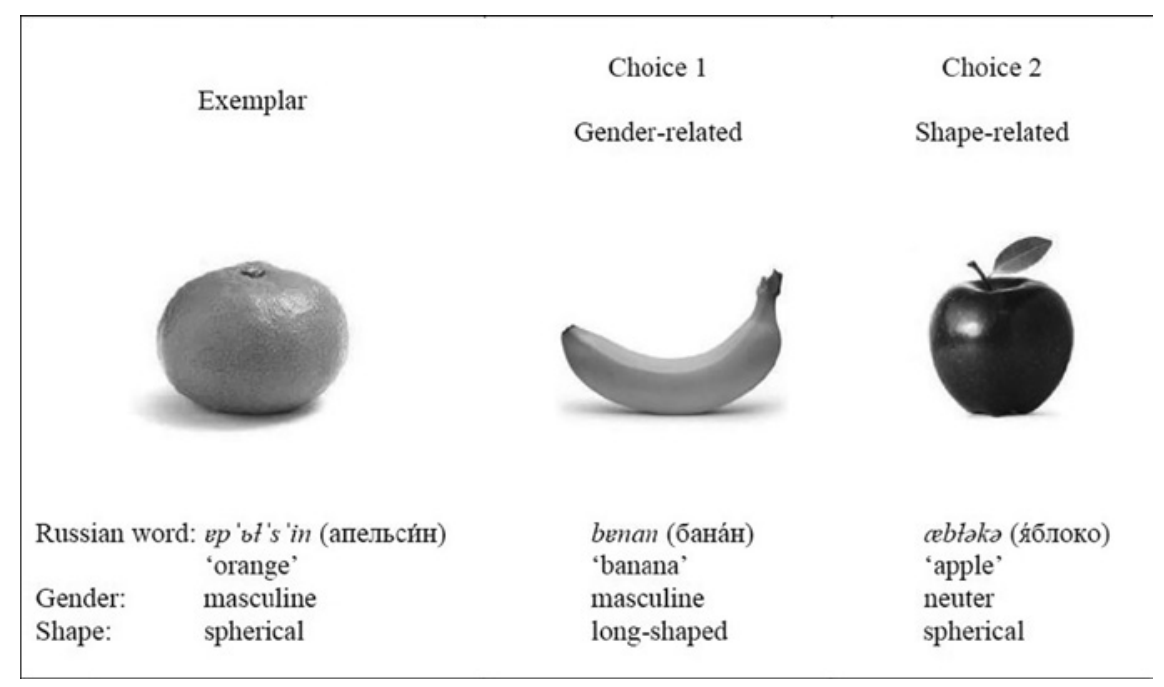

FIGURE 1 Example of a set of natural objects

\begin{tabular}{|c|c|c|}
\hline $\begin{array}{l}\text { Russian word: rutf'ka (ру́чка) } \\
\text { 'pen' } \\
\text { Gender: } \quad \text { feminine } \\
\text { Size: } \quad \text { small }\end{array}$ & $\begin{array}{l}\text { butifka (буть́лка) } \\
\text { bottle' } \\
\text { feminine } \\
\text { big }\end{array}$ & $\begin{array}{l}\text { noz (нож) } \\
\text { 'knife' } \\
\text { masculine } \\
\text { small }\end{array}$ \\
\hline
\end{tabular}

FIGURE 2 Example of a set of artifacts

parts. The first part presented the instructions for the experiment in the Russian language for Russian speakers and in the Thai language for Thai speakers. The second part was the test part which contained 11 sets of pictures which comprised 9 real sets and 2 control sets. The last part was a questionnaire about the participants' general information (sex and age). The answer sheet was provided in Russian for Russian speakers and in Thai for Thai speakers. 
There were 24 participants, all in the age range of 20-40 years old, split equally into two groups by sex and language (12 Russian and 12 Thai, 6 males and $6 \mathrm{fe}-$ males each). The former attended St. Nicholas' Orthodox Cathedral in Bangkok and the latter group was from the Faculty of Science and Technology at Thammasat University.

\section{$8 \quad$ Procedures}

Each participant was provided with an answer sheet for the test. All of them were tested individually. Before starting the experiment, they were told to read the instructions on the first page. According to Kousta and colleagues' study (2008), a 3 -second window is the proper time frame for memory-testing categorization experiments. Therefore, the participants were assigned to look at an exemplar picture for 3 seconds (counted by the researcher) and were then asked to determine which one of the two pictures on their answer sheet matched the first one. After the experiment had ended, we interviewed them to gather information about the criteria they used in selecting pictures in the test. The interview was conducted in both English and Russian for Russian speakers, depending on the individual speaker's preference, and in Thai for Thai speakers. Participants took part in the experiment in turn.

\section{9}

\section{Results of the Study}

The total score was 16 for Russian speakers and 5 for Thai speakers, as is shown in Table 3. The results of the analysis show that the Russian speakers chose more pictures that matched the given ones in terms of gender. Thus, they got higher scores compared to the Thai speakers.

To examine the result statistically, analysis of variance (ANOVA) was applied. ANOva reported significant differences of scores between the groups of Russian and Thai speakers ( $\mathrm{p}<0.01$, see Table 4 below).

This enables us to conclude that Russian speakers tend to group together things represented by nouns of the same gender but Thai speakers do not group things in this way and this seems to suggest that the grammatical category of gender in Russian influences Russian native speakers, while the absence of this grammatical category in Thai makes Thai speakers free to group things by other criteria, such as size or shape. To conclude in terms of 
TABLE 3 The total scores of Russian and Thai speakers

\section{Individual total score in an ascending format}

$(\max =9$ per person $)$

No. No. No. No. No. No. No. No. No. No. No. No. of total

\begin{tabular}{lccccccccccccc} 
Participants & 1 & 2 & 3 & 4 & 5 & 6 & 7 & 8 & 9 & 10 & 11 & 12 & score \\
\hline $\begin{array}{l}\text { Russian } \\
\text { speakers }\end{array}$ & 0 & 0 & 0 & 0 & 0 & 1 & 1 & 1 & 2 & 2 & 2 & 7 & 16 \\
$\begin{array}{l}\text { Thai } \\
\text { speakers }\end{array}$ & 0 & 0 & 0 & 0 & 0 & 0 & 0 & 0 & 1 & 1 & 1 & 2 & 5 \\
\hline
\end{tabular}

TABLE 4 Result of Analysis of Variance (ANOVA) for the object categorization experiment

F-Test Two-Sample for Variances

Russian speakers

Thai speakers

$\begin{array}{lcc}\text { Mean } & 1.333 & 0.417 \\ \text { Variance } & 3.879 & 0.447 \\ \text { Observations } & 12 & 12 \\ \text { df } & 11 & 11 \\ \text { F } & 8.678 & \\ \text { P(F<=f }) \text { one-tail } & 0.001 & \\ \text { F Critical one-tail } & 2.818 & \end{array}$

the Linguistic Relativity Hypothesis, it is safe to say that the more different the grammars of languages, the more different will be the cognition of the speakers of those languages.

\section{0 \\ Discussion}

Although the analysis of the object categorization of Russian and Thai speakers statistically indicates that grammatical gender is likely to have an influence 


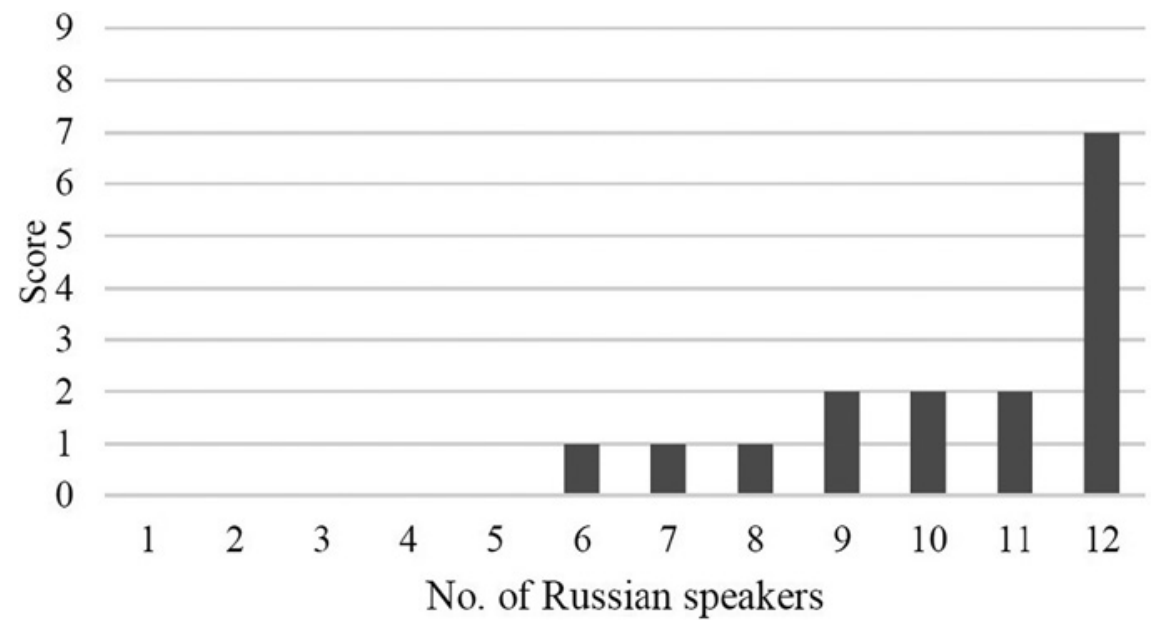

FIGURE 3 Individual total score of each Russian speaker in an ascending format

on Russian participants, most of the Russian speakers had lower scores than expected. Moreover, the individual scores of the Russian speakers show an unusual tendency; one participant had a very high total score (see Figure 3). This made us attempt to find some explanation.

So, we examined the interview data and found that this "highest score" participant was a monolingual Russian speaker who had lived in Thailand for only six months, while the rest were bilingual Russian-English speakers, who had lived in Thailand for at least one year. Some of them were married to Thais. Apart from Russian, they were able to speak both English and Thai. This particular fact raises the possibility that becoming a bilingual further modifies a speaker's cognition. In other words, bilingualism or multilingualism is likely to affect a test of the Linguistic Relativity Hypothesis.

Actually, research about bilinguals and cognition shows that there exists a ifference in perception and categorization of reality between monolinguals and bilinguals. For example, Cook et al. (2006), found that the result for Japanese-English bilinguals' similarity judgment on particular objects is not the same as that of Japanese monolinguals. Moreover, the result varied and depended on the length of residence in an English speaking country. JapaneseEnglish bilinguals who had lived in an English speaking country for over three years gave results close to that of English monolinguals while the results from Japanese-English bilinguals who had lived in an English speaking country for fewer than 3 years differed more. Furthermore, Kousta and others (2008) studied the influence of Italian grammatical gender in Italian-English bilinguals and found that Italian-English bilinguals resembled Italian monolinguals in a 
picture categorization experiment when they were asked to take part in the Italian language but resembled English monolinguals when they were asked to do it in the English language. Another research on the influence of languages on speakers' cognition in Thailand, Ruthirago (2011), studied the relationship between the grammar of Counterfactual and the cognitive system of Thai and German speakers. She found that Thai speakers who had learned German used less time in the experiment than Thai speakers who had never studied German. This result implies that language might have an influence on speakers, even if it is not the first language they learn.

These studies show that bilingual's and monolingual's cognitive abilities are different. Back to our research, the fact that the only one monolingual Russian participant got 7 out of 9 while other bilingual participants achieved considerably lower scores leads us to the conclusion that bilingualism influences its speaker's cognition.

\section{Conclusion}

This paper proposed a psychological method to investigate the influence of Russian grammatical gender on Russian speakers in a categorization task. The experiment focused on comparing the different picture-grouping policy of Russian speakers and Thai speakers, whose language has no grammatical gender. We found evidence of the influence of Russian grammatical gender on Russian speakers' cognition and this result was supported by a statistical analysis. In addition, the effect of bilingualism on the speaker's cognition was noted and would be an interesting topic for future research on the Linguistic Relativity Hypothesis.

\section{Acknowledgement}

This research was supported by The $90^{\text {th }}$ Anniversary of Chulalongkorn University Fund (Ratchadaphiseksomphot Endowment Fund).

\section{References}

Aemdit, C. 2015. "The Relationship between Grammatical Tense Marking and the Cognitive System: A Test of the Linguistic Relativity Hypothesis in English, Japanese, Chinese, and Thai." Ph.D. Thesis, Chulalongkorn University. 
Alvanoudi, A. 2014. Grammatical Gender in Interaction: Cultural and Cognitive Aspects. Leiden, the Netherlands: Brill. https://doi.org/10.1163/9789004283152.

Boroditsky, L., L. Schmidt, and W. Phillips. 2003. "Sex, Syntax, and Semantics." In Language in Mind: Advances in the Study of Language and Thought, edited by Dedre Gentner and Susan Goldin-Meadow, 61-79. Cambridge, Massachusetts \& London, England: The MiT Press.

Boutonnet, B., P. Athanasopoulos, and G. Thierry. 2012. "Unconscious Effects of Grammatical Gender during Object Categorization." Brain Research 1479: 72-79.

Chandharath, W. 2013. "The Relationship between Linguistic Honorifics and the Cognitive systems of Japanese, Thai, and English Speakers." M.A. Thesis, Chulalongkorn University.

Charunrochana, J. 1997. "The Relationship between Grammatical Gender and Sex in Hindi and German Speakers' World View." M.A. Thesis, Chulalongkorn University.

Charunrochana, J. 1999. "The Influence of Grammatical Gender on Hindi and German Speakers' Sex Categorization." MANUSYA:Journal of Humanities 2 (2): 13-28.

Charunrochana, J. 2000. "The Relationship between Nominal Grammatical Categories and the Cognitive system of Thai and English Speakers." Ph.D. Thesis, Chulalongkorn University.

Cook, V., B. Bassetti, C. Kasai, M. Sasaki, and J. A. Takahashi. 20o6. "Do bilinguals have different concepts? The case of shape and material in Japanese L2 users of English." International Journal of Bilingualism 10 (2): 137-152.

Corbett, G., 1991. Gender. Cambridge University Press.

Cubelli, R., D. Paolieri, L. Lotto, and R. Job. 2011. "The Effect of Grammatical Gender on Object Categorization." Journal of Experimental Psychology 37 (2): 449-46o.

Doleschal, U. 1993. "Genus als Grammatische und Textlinguistische Kategorie. Eine Kognitiv-funktionalistische Untersuchung des Russischen.” Ph.D. Diss., University of Vienna.

Doleschal, U. 1997. "O Vzaimosvjazi Grammaticeskoj Kategorii Roda i Pola [On the Interdependence of the Grammatical Category Gender and Sex]." In Verbal and Non-Verbal Interpretation of Gender Characteristics, edited by Aleksandr Xolod, 134155. Krivoj Rog: Mezdunarodnyj Issleddovatel'skij Centr Celovek-Jazyk-Kul'tura -Poznanie.

Eysenck, M. W., \& M. T. Keane. 2005. Cognitive Psychology: A Student's Handbook. Psychology Press Ltd.

Flaherty, M. 2001. "How a Language Gender System Creeps into Perception.” Journal of Cross-Cultural Psychology 32 (1): 18-31.

Forbes, J. N., D. Poulin-Dubois, M. R. Rivero, and M. D. Sera. 2008. "Grammatical Gender Affects Bilinguals' Conceptual Gender: Implications for Linguistic Relativity and Decision Making." The Open Applied Linguistics Journal 1: 68-76. 
Jakobson, R. 1966. “On Linguistic Aspects of Translation.” In On Translation, edited by R. A. Brower, 232-239. New York: Oxford University Press.

Kousta, S. T., D. P. Vinson, and G. Vigliocco. 2008. "Investigating Linguistic Relativity through Bilingualism: The Case of Grammatical Gender." Journal of Experimental Psychology: Learning, Memory, and Cognition 34 (4): 843-58.

Lakoff, G. 1987. Woman, Fire and Dangerous Things: What Categories Reveal about the Mind. Chicago: University of Chicago Press.

Lucy, J. A. 1992. Grammatical Categories and Cognition: A Case Study of the Linguistic Relativity Hypothesis. Cambridge: Cambridge University Press.

Pecher, D. and R. A. Zwaan. 2005. Grounding Cognition the Role of Perception and Action in Memory. The United States: Cambridge University Press.

Ruthirago, N. 2011. "The Relationship between the Grammar of Counterfactual and the Cognitive System of Thai and German Speakers: Linguistic Relativity Hypothesis Revisited." M.A. Thesis, Kasetsart University.

Whorf, B. L. 1956. Language, Thought, and Reality, edited by John B. Carroll. New York: MIT Press. 